\title{
Erratum to: Durvalumab: First Global Approval
}

\author{
Yahiya Y. Syed ${ }^{1}$
}

Published online: 10 October 2017

(c) Springer International Publishing AG 2017

\section{Erratum to: Drugs (2017) 77:1369-1376 \\ DOI 10.1007/s40265-017-0782-5}

The article "Durvalumab: First Global Approval", written by Yahiya Y. Syed, was originally published Online First without open access. After publication in volume 77, issue 12, pages 1369-1376 Springer Healthcare requested that the article be Open Choice to make the article an open access publication. Post-publication open access was funded by Springer Healthcare to test our procedures. Further details may be found at http://www.medengine.com/ Redeem/C898F06046BCED2D. The article is forthwith distributed under the terms of the Creative Commons Attribution-NonCommercial 4.0 International License (http://creativecommons.org/licenses/by-nc/4.0/), which permits any noncommercial use, duplication, adaptation, distribution and reproduction in any medium or format, as long as you give appropriate credit to the original author(s) and the source, provide a link to the Creative Commons license and indicate if changes were made.

The online version of the original article can be found under doi:10. 1007/s40265-017-0782-5.

Yahiya Y. Syed

dru@adis.com

1 Springer, Private Bag 65901, Mairangi Bay, Auckland 0754, New Zealand 